\title{
Karykaturalny obraz prześladowców narodu polskiego w niepublikowanej powieści Juliana Ursyna Niemcewicza Wladysław Bojomir
}

Małgorzata Chachaj 
nAPIS Seria XIV 2008

\section{Małgorzata Chachaj}

\section{Karykaturalny obraz prześladowców narodu polskiego w niepublikowanej powieści Juliana Ursyna Niemcewicza Wtadystaw Bojomir}

$\mathrm{P}_{\mathrm{b}}$ owieść Juliana Ursyna Niemcewicza zatytułowana Władysław Bojomir powstawała w latach 1827-1828. Nie została ukończona, rękopis kończy się po jedenastu rozdziałach. Utwór nie został wydany, co — biorąc pod uwagę jego zdecydowanie antyrosyjską i patriotyczną wymowę - nie dziwi. Rękopis Wtadystawa Bojomira obecnie znajduje się w Bibliotece Narodowej w Warszawie', zaś odpis w Bibliotece Czartoryskich w Krakowie ${ }^{2}$.

Powieść ma formę wspomnień młodego Polaka³. Władysław Bojomir już w pierwszym akapicie deklaruje chęć wystąpienia w roli „świadka wydarzeń nikczemnych, samowolnego okrucieństwa i niesłychanego szaleństwa" [s. 1] ${ }^{4}$. Chociaż daty nie są podawane (tylko raz Władysław wymienia rok 1826), to na podstawie czynionych aluzji i wspominanych wypadków ramy czasowe powieści można w przybliżeniu określić na koniec drugiego i trzecie dziesięciolecie XIX wieku. O prawdziwości prezentowanych wydarzeń przekonują odautorskie przypisy, w których Niemcewicz powołuje się na znane i szeroko komentowane ówcześnie fakty oraz przypomina osoby, które doświadczyły podobnych prześladowań co bohaterowie powieści.

\footnotetext{
${ }^{1}$ Rkps. Biblioteki Narodowej, sygn. BN BOZ 1057.

2 Rkps. Biblioteki Czartoryskich w Krakowie, sygn. 2221. Jest to bardzo dokladny odpis rękopisu warszawskiego — różnią się jedynie ilością zapisanych stron, gdyż egzemplarz krakowski pisany jest większymi literami.

3 Streszczenie podał A. M. Kurpiel (Pamiątkowa ksiega 1866-1906. Prace bytych uczniów S. hr. Tarnowskiego, t. 1, Kraków 1904).

${ }^{4}$ Numery stron podaję według rękopisu z Biblioteki Czartoryskich.
} 
Opowiadana historia rozpoczyna się w chwili, gdy Wladysław Bojomir ma 14 lat. Ojciec przywiózł go wówczas do stolicy, by kontynuował naukę w Liceum Warszawskim. Już pierwszego dnia, gdy przyglądał się paradzie wojskowej, doświadczył przemocy ze strony wielkiego księcia. Zwrócił on uwagę na "gęste ciemnoorzechowe pierścienie włosów obficie" [s. 2] upadające Władysławowi na ramiona. Fryzurę uznał za dowód karbonaryzmu, toteż młodzieńca ogolono na łyso.

W szkole Wladysław otoczony był szpiegami i donosicielami, rekrutującymi się zarówno spośród uczniów, jak i nauczycieli oraz funkcjonariuszy państwowych. Jeden z kolegów, Szelmowicz, wykorzystując prostoduszność, brak ostrożności i naiwność chłopca, zaprowadził go do Nowosilcowa. Młodzieniec zdecydowanie odrzucił propozycje współpracy z Rosjanami i wyparcia się polskości, za co zostal straszliwie ukarany. Donosiciele nie odstępowali go na krok, zapisywali każde wypowiedziane słowo, by postawić Władysławowi zarzut nieprawomyślności. Niedługo potem (był w piątej klasie) na jego ławce szkolnej pojawił się napis: „Vivat Kanstytucja 3 maja. Smert tyranom” [s. 64]. Na próżno się bronil, dowodząc, że forma zapisu wskazuje na autorstwo Rosjanina, a nie Polaka - został wtrącony do więzienia. Mimo ciężkich tortur nie przyznał się do winy, nie potwierdził swej przynależności do tajnych związków, nie próbował ratować życia przez podpisanie podsuwanych mu fałszywych, obciążających kolegów zeznań. Kolejny etap jego męki to służba w wojsku rosyjskim, gdzie codziennie doświadczał upokorzeń i miał sposobność przypatrzenia się demoralizacji ówczesnych władz. Ciężko chory trafił do szpitala, gdzie odnalazła go matka (ojciec, po bezowocnych próbach wydostania syna z niewoli, zmarł już wcześniej). Bojomirowa porusza niebo i ziemię, by ratować syna. Zbieg okoliczności sprawia, że poznaje Nowosilcowa, ten obiecuje pomoc, ale cena, jakiej żąda, jest nie do przyjęcia. Senator chce, by wychowanica pani Bojomir - a była nią córka Józefa Kalasantego Szaniawskiego z pierwszego małżeństwa - została jego kochanką. Władysław broni młodą kobietę przed gwałtem, za co zostaje ponownie wtrącony do więzienia. W tym czasie Nowosilcow ponownie próbuje zniewolić dziewczynę. Dopiero pomoc drugiej żony Szaniawskiego, która oskarżyła Nowosilcowa przed wielkim księciem, okazuje się skuteczna — młodzieniec uzyskuje zwolnienie $z$ więzienia i ze służby. Życie Władysława nadal nie toczy się pomyślnie, umiera jego matka. Przed śmiercią godzi się na małżeństwo syna z Ludomiłą Szaniawską. Władysław powraca na wieś, odzyskuje spokój, zajmuje się gospodarstwem, rodzi mu się syn, cieszy się szacunkiem sąsiadów. Jednak jego szczęście nie trwa długo. Zostaje wybrany na sejmiku — wbrew instrukcjom rosyjskim — posłem na sejm. Ma odwagę protestować przeciwko próbie sfałszowania wyborów, a później protokołu. Bezkompromisowość i odwaga w bronieniu zasad konstytucyjnych ściagają na niego kolejne kłopoty w Warszawie, car wciąga go na listę swoich wrogów. Na kolejny sejm nie zostaje wpuszczony pod pretekstem niesplacenia rzekomych długów. Powraca do domu, ale aparat represji ściga go i tam. Powieść kończy scena aresztowania Wladysława. Wykonujący rozkaz żołnierz nie potrafi podać powodu zatrzymania. 
Powieść Wtadystaw Bojomir nawiązuje do ówczesnych wypadków, autor relacjonuje dramatyczne doświadczenia Polaków, rejestruje przejawy zła, okrucieństwa i przemocy w życiu społecznym, dokumentuje martyrologię narodu skazanego na zagładę. Już pobieżne streszczenie utworu daje wyobrażenie o nastroju dominującym w powieści — jest poważny, smutny, patetyczny. Niemcewicz jednak doskonale wiedział, że opowieść o sytuacji Polaków utrzymana wyłącznie w tonie dramatycznej powagi może paraliżować i odbierać odwagę. Remedium na przerażającą rzeczywistość mógł stać się śmiech, a konkretnie - ośmieszenie przeciwnika, czy bezkompromisowa dyskredytacja wroga. Jak zauważają historycy literatury różnych epok, podczas największego ucisku, w tragicznych dla narodu chwilach zawsze rodzi się potrzeba śmiechu, który pozwala zwyciężyć nad strachem. Komizm oswaja zło, gdyż wyśmiewając, pomniejsza je. Śmiech pełni wówczas rolę kompensacyjną i konsolacyjną̧5.

Niemcewicz postaci rosyjskich oprawców i polskich zdrajców pokazał w komicznym świetle, ale — co należy podkreślić - nie wyłącznie karykaturalnie, bo nie fałszował historii. Posłużył się ironią, satyrą, sarkazmem i kpiną. Mechanizmem wywołującym komizm jest degradacja ${ }^{6}$. Służą temu celowi: odpowiednie zestawienie faktów, jednostronna selekcja, przesada, pewne zdeformowanie rzeczywistości. Niebagatelną rolę odgrywa również posłużenie się kontrastem ${ }^{7}$, zwłaszcza wzmocnienie podziału: „my — oni”". Prześladowcy to prymitywni głupcy, pijacy, rozpustnicy o odrażającej fizjonomii i niskiej kulturze osobistej, bliżsi zwierzętom niż rodzajowi ludzkiemu' ${ }^{9}$. Oczywiście, Niemcewicz nie ukrywa, że są groźni i trzymają w swoich rękach los prawych

\footnotetext{
${ }^{5}$ Por. np. prace: B. Dziemidok, O komizmie, Warszawa 1967; Z. Jastrzębski, Poetyka humoru lat okupacji 1939-1944, Warszawa 1986; J. Kleiner, Z zagadnień komizmu, w: idem, Studia z zakresu teorii literatury, Lublin 1961; E. Pogonowska, Panistwo ponurej anegdoty, w: Dzikie biesy. Wizja Rosji sonvieckiej w antybolszewickiej poezji polskiej lat 1917-1932, Lublin 2002; J. Ziomek, Komizm-spójność teorii i teoria spójności, w: idem, Powinowactwa literatury. Studia i szkice, Warszawa 1980; K. Żygulski, Wspólnota śmiechu. Studium socjologiczne komizmu, Warszawa 1985.

${ }^{6}$ Por. J. Ziomek, Komizm..., op. cit., s. 321.

7 Zob. ibidem.

${ }^{8}$ Por. K. Żygulski, Wspólnota śmiechu, op. cit., s. 21: „Ten, kto się z nami śmieje, należy do naszej wspólnoty, kto śmieje się z innymi, jest kulturalnie w pewnym sensie obcy".

9 Magdalena Rudkowska w interesującym artykule Niemcewicz i Rosja (w: Julian Ursyn Niemcewicz. Pisarz, historyk, świadek epoki, red. J. Wójcicki, Warszawa 2002, s. 101-117) przypomina opinię o Niemcewiczu jako apostole nienawiści, sformułowaną przez Stanisława Tarnowskiego, a później chętnie powtarzaną. Przytacza także sądy polemiczne, m. in. Ignacego Chrzanowskiego, który w Pochwale Niemcewicza (1927) pisał: „Zapewne nie kto inny, tylko Niemcewicz wszczepił w duszę polską ową "chorobę na Moskala", o której mówi Żeromski. Ale o wiele słuszniej podobno nazwał go Klaczko "stróżem narodowej godności» - dlatego słuszniej, ze nienawiść Rosji i złych Polaków była w duszy Niemcewicza tylko cieniem, które rzucało słońce miłości Polski, gorejące w jego sercu, i dlatego jeszcze, że ta jego nienawiść uświadomiła społeczeństwu ohydę godzenia się z niewolą. Więc nie potępiajmy za to Niemcewicza - owszem żałujmy raczej, że nie zaszczepił w sercach polskich także choroby na Prusaka i choroby na Austriaka" (ibidem, s. 101).
} 
Polaków, ale ta świadomość nie powinna paraliżować strachem. W karykaturalnym, czy niekiedy wręcz groteskowym przedstawieniu negatywnych bohaterów, ważna jest reakcja psychiczna odbiorców. Rodzić się w nich ma poczucie siły ${ }^{10}$.

Niemcewicz obwiniał Rosję za upadek Polski. Początkowo była ona dla niego przeszkodą na drodze do odzyskania suwerenności, potem zaś państwem niszczącym wszystko, co polskie, skazującym Polaków na śmierć lub wygnanie, odbierającym im ziemię, język, tradycję, niszczącym pamięć o przeszłości. Do ukształtowania się takiej postawy przyczyniły się dramatyczne losy ojczyzny, ale i wydarzenia w życiu osobistym (więzienie, prześladowania, konieczność emigracji). Niechęć do państwa — symbolu wcielonego zła - nie przekładała się na niechęć do calego narodu ${ }^{11}$. Ostrze krytyki skierowane było przeciwko tym, których rękami dokonywały się prześladowania ${ }^{12}$. Osobą, którą Niemcewicz szczególnie nienawidził ( $z$ wzajemnością) i piętnowal w swoich utworach, był senator Mikołaj Nowosilcow, nazywany przed niego stale Zyzowatym lub Zyzakiem. Kpi sobie z niego bezlitośnie także w powieści Wtadystaw Bojomir. Zanim pojawi się on sam, czytelnik poznaje go z opowiadania Szelmowicza. Przedstawia on Władysławowi Nowosilcowa, bez wymieniania nazwiska, jako pana „nieoszacowanego, najpierwszego u nas znaczenia, wszystko on u nas może, wszystko prowadzi, wszystkim rządzi”, „lubi młodzież, proteguje studentów i bardzo jest nam przychylnym" [s. 7]. Pozytywne nastawienie czytelników zostaje szybko zweryfikowane, zaskoczenie odbiorców wiąże się z ujawnieniem nazwiska „ideału”. Ale to zaskoczenie jest potrzebne, by podkreślić kontrast pomiędzy wyobrażeniem, kim powinna być osoba piastująca ważne stanowisko państwowe, a zachowaniem Nowosilcowa. Niemcewicz podkreśla nieprawość charakteru senatora, akcentuje jego fałszywe zachowania. Szyderstwo ma zniszczyć osobę, zdeprecjonować ją, unicestwić w życiu publicznym. Charakterystyka postaci budowana jest zatem z zachowań odbiegających od normy, niestosownych, dziwacznych, dwuznacznych. Niemcewicz nie poprzestaje na wyliczeniu wad, ale stosuje przesadne wyolbrzymienie.

10 Por. uwagi K. Żygulskiego, Wspólnota śmiechu, op. cit., s. 78. Pisał on, że obrazy ośmieszonego przeciwnika „utwierdzają wspólnotę w poczuciu wyższości siły, redukują strach, działają integrująco, są dodatkowym dowodem posiadania słuszności w konflikcie".

${ }^{11}$ Przypomnieć tu wystarczy wielkie nadzieje, jakie Niemcewicz wiązał z Aleksandrem I, co sprawiło, że pisał o nim z czcią i szacunkiem.

${ }_{12}$ Nie sposób nie zgodzić się ze zdaniem Magdaleny Rudkowskiej (op. cit., s. 101): „Trudno powiedzieć, gdzie kończy się indywidualna obsesja, gdzie zaś zaczyna się polityczna konieczność nieustannego spoglądania na Wschód czy raczej — jak powiedziałby człowiek XVIII wieku - na Północ. Niemcewicz nie mógł zapomnieć o Rosji nie tylko dlatego, że został ukształtowany przez specyficzną tradycję rodzinną i narodową oraz bolesne doświadczenie petersburskiego więzienia, ale też dlatego, że jego udziałem stał się silnie upolityczniony wariant życia prywatnego". W podsumowaniu artykułu autorka stwierdza: „Niemcewiczowska wizja Rosji — dramatyczna, dynamiczna, ambiwalentna — świadczy o tym, że wbrew swej legendzie apostoła nienawiści pisarz nie definiował raz na zawsze stosunku Polski wobec Rosji, zapowiadając w ten sposób poszukiwania XIX i XX wieku" (ibidem, s. 117). 
W opisie domu Nowosilcowa podkreślone zostały dwa elementy, związane z pijaństwem i obżarstwem gospodarza — „niezmierne kufry” z różnymi winami w sieni oraz stale zastawiony stół $\mathrm{z}$ pozłacanym serwisem. Zachowanie senatora szybko zdradza jeszcze jedną słabość — rozpustę. To są elementy charakterystyki, które się nieustannie powtarzają na kartach powieści. Nowosilcow cały czas pije, niemal każda scena, w której się pojawia, podkreśla ten fakt. Wydaje się, że nigdy nie trzeźwieje - „codziennie miasto całe widzi go taczającego się po ulicach”. Sceny ośmieszające bohatera są rozbudowane. Jedna z wizyt u Pani Bojomirowej i Ludomiły wyglądała następująco:

Słychać było taczające się dźwiganie po schodach, i jak gdyby uderzanie się w ściany. Wszedł na koniec senator w bogatym haftowanym mundurze, z mnóstwem rozmaitych orderów, z kapeluszem strusimi piórami, czerwony jak burak, i tak okropnie buchający rumem i winem, iż zdawał się jak smok piekielny, zionący smrodliwe płomienie. Chcial coś mówić, lecz równie jak nogi, tak i język jego plątały się [s. 276].

Był obcesowy i wulgarny. Nagle "Nowosilcow, wyciaggnąwszy nogi jak długi, i oparłszy głowę o ścianę, potężnie chrapać zaczął. [...] pijany senator wielce się pienił” [s. 279] — czytamy w powieści Niemcewicza. Autor nie szczędzi czytelnikowi odrażających szczegółów:

[Bajkow] zawołał służących jego i swoich. Ci z wielką pracą podniósłszy senatora z kanapy, wyprowadzili go z pokoju. Większa nierównie była trudność sprowadzenia go po schodach. Wkrótce niesłychane dało się słyszeć krztuszenie, senator bowiem z strasznym łoskotem wypróżniał na schody cały swój obiad, wszystkie wlane w siebie wina, portery, poncze i rumy [s. 283].

Wyolbrzymieniu niskich cech bohatera powieści służy również posłużenie się przez autora depersonalizacją, a właściwie zoomorfizacją. Senator „śmierdzi jak zwierzę”, zachowuje się jak zwierzę, wydaje podobne odgłosy — „rży i kwiczy”, „pieni się”. Nazwany jest „poczwarą" i „odrażającym monstrum”. Autor portretuje go w sposób karykaturalny, używa dosadnych epitetów, bezpardonowo natrząsa się z defektów urody, ułomności, dolegliwości czy deformacji ciała. Oto jeden z opisów:

Twarz ciemnym rozpromieniona ponsem, oczy zyzowate, na próżno sznurując usta w zdradliwy uśmiech, by nim zakryć zęby spróchniałe, chciał się ukazać uprzejmym, przemagał mocniejszy nad wszystko wyraz zlości, fałszu i obłudy [s. 26].

I podobny obraz: 
wszedl Zyzowaty senator i sznurując wargi, by spróchniałe zęby swe zakryć, strzelając jednym okiem w prawo, drugim w lewo [s. 265].

Fizyczne ułomności i skazy wyglądu to nie wszystko - karykaturalne ujecie dotyczy także celowej deformacji czy wykoślawienia zachowań, sugerujących, że mamy do czynienia z osobą niezrównoważoną psychicznie. Jako przykład może posłużyć scena, kiedy senator snuje plany ostatecznej rozprawy z Polakami. Groźby wypowiada „z diabelskim uśmiechem” „zacierając ręce, miotając iskry z zyzowatych swych oczu”, po czym — jak dziecko — „zaczął skakać z radości” [s.165].

Elementem doskonale charakteryzującym senatora jest przeplatanie słów polskich i rosyjskich, jak też używanie zdrobnień i częste wplatanie w tok wypowiedzi rosyjskich wulgaryzmów. Podkreślona jest w ten sposób jego obcość, ale też prymitywizm. Zyzowaty budzi obrzydzenie także dzięki językowi, którym się posługuje. Najbardziej wyrazisty wydaje się następujący przykład:

Najwyższy władca choćby się omylił, nigdy się nie cofa. Wyroki jego są jak ezkrementa, które gdy raz wyjdą z brzucha, nie wracają doń nazad [s. 117].

Niemcewicz ujawnił w ten sposób zarówno negatywne strony Nowosilcowa, jak i reprezentowanego przezeń systemu politycznego.

Nieodlączny towarzyszem Nowosilcowa był Bajkow. Matka Wladysława o swoim pierwszym wrażeniu przy spotkaniu z nimi opowiadała następująco:

dwóch ichmościów, jak mi się zdało nie naszych, jeden z nich wysoki, gruby, drugi szczuplejszy, lice jego karmazynowym pałały rumieńcem, czarna szorstka brodawka pod okiem, wśród liców tych zdawała się pływać jak we krwi, usznurowane wąskie usta, oczy ukosem biegające we wszystkie strony. Przyznam się, iż postacie takie, zrazu wstręt jakiś we mnie wzbudzily [s. 246].

Bajkow, cień i echo Nowosilcowa, tłumaczy wszelkie jego potknięcia, jest jego stręczycielem i posłańcem. Na przykład o pijaństwie senatora mówi:

Ten zacny mąż ledwie kiedy kieliszek wina wypije, lecz dziś są jego imieniny, przyjaciel od serca dawał na cześć jego obiad, dawane rozmaite wina, senator kosztował je tylko, lecz że nieprzyzwyczajony, rozmarzył się nim, jak widzicie, pierwszy raz w życiu zdarzył mu się ten przypadek [s. 281].

Autor sugeruje odbiorcy negatywne oceny, postaci wrogów mają budzić wstręt. Karykatura staje się narzędziem walki politycznej. 
Trzecią postacią, na którą trzeba zwrócić uwagę, jest wielki książę. Budzi przerażenie, wokół niego panuje martwa cisza, napady szaleństwa pozbawiają ludzi życia lub wolności. Przywołajmy jeden cytat:

Z razu chciwi widzenia monarchy, lubo już wojskowymi napełnione pokoje, zebrali się atoli najpierwsi kraju urzędnicy, kiedy niespodzianie, jak dzik, kiedy go ogary osadzą, pieniąc się i parskając straszliwie, wpadł Wielki Kniaź, wołając: „won sztatskie, won sztackieie” (precz cywilni), wzmacniając głos ten następowaniem i kopaniem nogami. Trzeba było widzieć naówczas, jak uginający się pod ciężarem wieku prezes senatu, osiwieli senatorowie, przełazili otaczające salę krużganki, i ile wiek pozwolił, spiesznie schodami spuszczali się na dót. Nie zostało, jak same żołnierstwo! [s. 218].

W przywołanej scenie autor zmierza do udowodnienia czytelnikom, że człowiek ten jest pozbawiony wartości, którą mu się przypisywało $z$ racji pełnionego urzędu, chciał zdemaskować szaleńca. Także i w tym przypadku posłużył się Niemcewicz kontrastem, wydobył sprzeczność pomiędzy tym, jak powinno być, a tym, jak jest. Jest to oczywiście śmiech podszyty grozą, ale autor nie cofa się przed agresywnym dyskredytowaniem i ośmieszaniem bzdurnych pomysłów, aplauzu zgrai pochlebców, prostactwa, głupoty, okrucieństwa, ordynarności.

Już początek rozdziału I przynosi pierwszy opis wyglądu i zachowania wielkiego księcia Konstantego:

Przebóg, co to za zakazana postać, twarz czworograniasta, nosa prawie żadnego, oczy dzikie, brwi zupełnie białe. Wrzeszczał chrapliwym głosem, pianę z ust pryskając, stojący przy nim zdawali się skamieniałymi od strachu $[\ldots]$ czerwony, zapieniony, zdjęty najżywszą zapalczywością [s. 2].

Podobnie jak w przypadku Nowosilcowa, Niemcewicz zastosował deprecjonujący opis - Konstanty jest podobny do dzikiego zwierzęcia, trywialny, niski, śmieszny i godny pogardy, a nie wielki. W opisie dominuje wyrazistość i przesada, by wywołać u czytelnika obrzydzenie.

Cechą bardzo podkreślaną w charakterystyce wielkiego księcia jest jego głupota stary żołnierz radzi zaczynającemu służbę Władysławowi:

strzeż się, żebyś nigdy żadnej książki nie tylko nie czytal, ale nawet nie miał u siebie. Wódz nasz oświadczył, iż do dwóch klas ludzi wstręt czuje największy, to jest do Żydów i do uczonych. Im się głupszym okażesz, tym więcej będziesz cenionym [s. 132]. 
Nowosilcow zaś odkrywa jego słabość, zdradzającą kolejne godne potępienia cechy charakteru, ale i infantylizm Konstantego. Przy przeglądaniu papierów uwięzionych Polaków wyjawia:

co do spraw domowych, intryg miłosnych, zaniosę do Belwederu, niezmiernie bowiem W[ielki] Książę lubi to i umie się tym bawić, rad wiedzieć wszystko, co się dzieje nie tylko w każdym domu, ale w łóż$\mathrm{ku}$, a nawet pod lóżkiem. W czasie ostatniej wojny kazal sobie całe torby pocztowe przynosić, otwieral wszystkie listy i czytal. Zdarzało się nieraz, że w tłumie tym znalazły się listy mężów do żon, kochanków do kochanek; cóż robi Konastanty Pawłowicz? Oto bierze listy pisane przez kobiety zamężne do kochanków ich i kładzie je pod kopertę i adres mężów, i nawzajem, a gdy wkrótce dowiedział się o niesłychanych stąd scenach, zazdrościach, rozwodach nawet, pękał się od śmiechu z tak niewinnego i razem dowcipnego figla. Owoż spodziewam się, że i teraz znajdziemy coś podobnego, co zabawi Welikoho Kniazia... [...]

To wyborne, listy strzeliste, pełne najczulszej miłości Pani N.N. do putkownika N.N.; ach, muszę je zanieść Jeho Carskomu Wysoczestwu, ach, jakże się zabawi, jakże będzie śmiał, zapewne je mężowi tej pani poszle [s. 168].

W karykaturalny sposób przedstawil autor także przywiązania wielkiego księcia do porządku i dyscypliny. Przypomnijmy scenę, gdy Władysław ma pełnić służbę u Konstantego:

Dopiero zaczęto mię ubierać, to jest obszyto całkiem w spodnie, mundur i kamasze, tak ciasno, iź żadnym sposobem kolan zgiąć nie mogłem, w pasie tak byłem ściśnięty, żem ledwie oddychał. Największa biada, gdy po schodach iść przyszło; zaczęły po schodach pękać i pruć się portki, sprowadzono mię więc na dół, obszyto na nowo, a dla uniknienia dalszych przypadków, przyszło dwóch żołnierzy, zaniosło na górę i postawiło w sieni, jak martwą woskową figurę [s. 123].

Obnażanie domniemanej nicości Konstantego i reprezentowanego przez niego porządku prawnego i państwowego - to jest strategia obrony. Ważne było uświadomienie czytelnikom słabości przeciwnika i własnej siły Polaków.

Oprócz Rosjan do grona prześladowców narodu polskiego należeli urzędnicy i zdrajcy, którzy zaprzedali się zaborcy. Wśród wysługujących się Rosjanom Polaków szczególnie odrażającą figurą jest Józef Kalasanty Szaniawski. Sposób prezentacji tej postaci wyróżnia maniera humorystyczno-ironiczna, posługiwanie się uproszczeniem, szyderstwo, naśmiewanie się, które ma na celu zniszczenie i pognębienie postaci. Na- 
zywany jest „infamisem w czerwonej peruce”, poczwarą, monstrum i psem. Sam o sobie mówi:

jak pies parszywy włóczę się po garkuchniach i pożeram tam sztuki rozmaitego mięsa, już rok szósty chodzę w tej jednej peruce czerwonej [s. 18].

Podobnie wyraża się o nim żona:

wygnany sam ze wszystkich uczciwych towarzystw, nie uczęszcza, jak do Moskali lub po garkuchniach pożera reszty niedojedzonych gnatów [s. 50].

Tłumaczy, że dała się oszukać, uwierzyła w patriotyzm Szaniawskiego:

dla tych to szlachetnych uczuć (zapewne nie dla figury, bo cóż szkaradniejszego być może) dałam mu rękę i majątek mój [s. 49].

Niedostatki urody, o których wspomina żona, prowokują do nazywania Szaniawskiego „Krzywogłowem”. Zaś nieuczciwe rozstanie z pierwszą żoną sprawia, że jest również powszechnie nazywany „bigamem”. Sprawuje funkcję cenzora, do czego — jak podkreśla autor - predestynuje go wyjątkowa głupota i lizusostwo. Szczyci się tym, że nie myśli, a jedynie wykonuje rozkazy. Wyróżnia go niezwykła duma i samozadowolenie. Wymowne jest obwieszanie się orderami, co zostało opisane w następujący sposób:

widziemy go przepasanego orderami, posypanego gwiazdami, z tylu krzyżami, krzyżykami na piersiach, na bokach, tak że się z nich geografii wszystkich państw europejskich uczyć można [s. 172].

W licznych wypowiedziach o charakterze samooskarżenia demaskuje się jako karierowicz i człowiek amoralny, kierujący się niskimi instynktami. Nie poczuwa się do pomagania pierwszej żonie, odrzuca córkę — jest gotów „odstąpić wszelkie prawa do niej" Nowosilcowowi. Przyjmuje przy tym obłudną pozę człowieka niezwykle religijnego, oczywiście czyni to na pokaz:

postrzegłem go nareszcie klęczącego w konfesjonale, w rudej swojej peruce. Acz daleki w tej chwili od śmiechu, wstrzymać się od niego nie mogłem, patrząc na grymasy i wykrzywiania się jego, lecz gdy przyszło do podniesienia, oczy jego, usta, piersi, zdawały się w najgwałtowniejszych konwulsjach, płakal, wzdychał, jęczał. [...] Skończyło się nabożeństwo, Krzywogłów wylazł z konfesjonału i klęknąwszy przed ołtarzem, długo lizał ziemię i potężnie bil czołem o kamień [s. 317].

Narrator zachowuje się jak nieświadomy rzeczy obserwator, który jedynie rejestruje zachowania. Nagromadzenie zachowań odbiegających od normy, komiczna deforma- 
cja, celowa redukcja, przesadne wyolbrzymienie i technika demistyfikacji służą degradacji oraz potęgowaniu u odbiorcy uczucia wstrętu.

Niemcewicz wspomina też o wielu innych polskich wykonawcach rosyjskich rozkazów, nazywanych przez Nowosilcowa jego psami (np.: ,jeszcze moich ogarów: Rożnieckiego, Axamitowskiego, Lubowickiego, nie widać” [s. 167]; „Ale gdzież są moje suki syny?” [s. 169]). O Józefie Zajączku mówi z pogardą:

stary Namiestnik nosa nie utrze bez mego pozwolenia, i byleby tylko mógł do śmierci dobrze jeść, pić i brać pieniądze, słyszyć się nazywanym książęciem, gdybym mu kazał zapalić na czterech rogach Warszawę, sam o kuli poleci z pochodnią i ogień podłoży [s. 170].

Zaś Stanisław Grabowski, stojący na czele resortu edukacji, w ocenie Nowosilcowa to kręcąca się na wszystkie strony małpa, bez zdania i własnej woli, jest to machinka, na której Szaniawski gra, jak na pozytywce, lecz nie inną arię, tylko tę, którą ja im przepiszę [s. 170].

Maurycy Hauke, zastępca ministra wojny,

całkiem jest moim; wól ten dobry jest na Namiestnika, równie w jarzmie będzie dobrze chodził, jak jego poprzednik [s. 174].

Zdegradowani do roli zwierząt, poniżeni oceniającymi epitetami, odarci z powagi i majestatu są ostatecznie skompromitowani i unieszkodliwieni — nikt ich nie szanuje, nawet ich mocodawcy.

Sposobem ośmieszania jest też oczywiście pomniejszanie postawy, opis zachowań odbiegających od wyobrażeń o danej osobie, jak w scenie gniewu Zajączka: „Nie niczym jest dmuchanie i parzchanie oszczepem zranionego odyńca, rzucał się, pienił, ciskał, porywał do kul swoich" [s. 447]. Podobnie wykpiony i pomniejszony został budzący grozę Jan Hankiewicz, sekretarz generalny Komisji Rządowej Sprawiedliwości, nazywany „szatanem” - podsłuchuje spowiedź Bojomira skulony za parawanem w bardzo niewygodnej pozycji, a przyłapany na tym, jest zmieszany i nie potrafi się wytlumaczyć.

Osobna grupa to donosiciele. Najbardziej wyrazistą postacią jest wśród nich Szelmowicz, młodzieniec liczący 17 lat, zabiegający o przyjaźń i ufność innych uczniów. Narrator skupia się na jego zachowaniach, pomijając komentarz:

układny, oczu bystrych, niespokojnych, latających we wszystkie strony, zdawało się, że nie tylko przy głowie, ale we wszystkich członkach ciała swego miał uszy, tak dalece, że najdalej i najciszej powiedziane słowo już go doszło, w wypytywaniach niezmordowany, bystrymi oczkami swymi 
śledzący wszystko, i tak ciekawy, że gdy który z nas pisał regestr bielizny do prania, on póty nie miał pokoju, póki go nie przeczytal. Ustawicznie szperał w seksternach, tekach, stolikach naszych. Nie dość, że wszystko chciał wiedzieć, co się w stancji naszej i klasie działo, wypytywał nas ustawnie o rodziców, jak oni myśleli, kto u nich bywał, o czym tam mówiono i tym podobne. Uważałem, że chociaż jegomość ten nie bardzo się dobrze uczył, przecież wyżsi wielkie mieli dla niego względy. Zdawał się on być okryty tarczą opiekuńczego bożyszcza jakiegoś. Często nie bywał na obiedzie w domu, powracał wtenczas czerwony, dobrze — jak się mówi — mający w czubku, z pełnymi kieszeniami rozmaitych cukierków i suchych konfitur [s. 7].

Niemcewicz ukazuje amoralne zasady rządzące mechanizmem ustroju, opartego na przymusie, przemocy, szpiegostwie. Jest bezkompromisowy w wyrokowaniu o wartości tych ludzi. Ich potępienie i ośmieszenie służy pokazaniu pewnych norm charakteru i moralności, które nigdy nie mogą być przekraczane, budowaniu systemu wartości obowiązującego każdego Polaka w sytuacji niewoli.

$\mathrm{Na}$ pewno liczył się z możliwą reakcją wyśmianych, oburzeniem, chęcią zemsty, niejednokrotnie tego doświadczał. Pamiętał cały czas, że ten obnażany i wyszydzony prymitywizm aparatu władzy jest groźny. Nie cofnął się jednak przed ostrą, zjadliwą, ironiczną oceną, demonstrowaniem dezaprobaty, uszczypliwością, kpiną i wartościującą refleksją. Jego celem było niewątpliwie poprawienie społecznego nastroju, kształtowanie opinii, pokazanie, że zło można osłabić, unieszkodliwić. Czytelnik reaguje śmiechem oczyszczającym, dającym siłę, przezwyciężającym ból, chroniącym przed rezygnacją i słabością. Taki śmiech jest dowodem siły narodu i społeczeństwa. 